\title{
Achieving Educational Effectiveness Using ICT Tools in the Development of Competence in the Design and Modeling of Clothing in the Organization of Specialized Disciplines
}

\author{
Umarova Fotima Abdurahimovna \\ *Corresponding Email: umarova-fotima@mail.ru \\ Doctoral student of Tashkent State Pedagogical University, Uzbekistan
}

Received: December 29, 2020

Revised: January 28, 2021

Accepted: February 12, 2021

\begin{abstract}
This article discusses the implementation of information and communication technologies in the field of vocational education in the field of costume design, analysis of their use, training of teachers to improve the effectiveness of education using information and communication technologies. In this article discusses the development of students 'competence in designing and modeling clothing using modern information and communication technologies in the training of specialists, increasing students' knowledge and skills, interest in the learning process and the ability to apply their knowledge in practice in the future. The focus will be on developing appropriate strategies for the new education role. The data show that the use of information and communication technologies in the educational process helps to increase the effectiveness of education and facilitates the organization of the learning process. In particular, it shows that the contribution of information and communication technologies to the improvement of the educational process in educational institutions, where information and communication technologies are an innovative factor. Achieving this high level means that the educational institution must not only modernize the technological tools, but also change the teaching models.
\end{abstract}

Keywords: Computer-Aided Design Systems, Production Technology Automation Systems, Light Industry, Textiles and Fashion

\section{Introduction}

Today and the future of our country are in the hands of our highly educated and enlightened youth. The reform of the continuous education system in the Republic of Uzbekistan is aimed at the highest professional culture, creative and social activity, the formation of a new generation that will independently participate in public and political life (Respublikasining, 1997; Karimov, 1997).

In the Decree of the President of the Republic of Uzbekistan dated October 8, 2019 No. PF5847 "Concept for the development of the higher education system of the Republic of Uzbekistan until 2030", it is planned to implement the introduction of digital technologies and modern methods in the educational process, ensuring the strong integration of modern information and communication technologies and educational technologies, continuous professional development of teachers in this area: creation of additional conditions for development; individualization of educational based on digital technologies, widespread introduction of webinars, online, "blended learning", "flipped class" technologies into practice; one of the most important tasks is the organization of software distance learning based on modern information and communication technologies (qizi Umarova, 2020).

Advanced countries and regions, which are working effectively to introduce digital technologies in education and create a digital learning environment, are showing high quality 
education results (qizi Umarova, 2020). The rapid development of digital technologies in the modern world requires pedagogy to keep up with trends (Uden et al., 2007)

In the educational process, computer technology performs several functions and is implemented as a subject, a teaching tool and a means of solving professional tasks, which creates a radically new situation in teaching: the teaching staff of the educational institution is tasked with integrating pedagogical education and information technology.

The use of computer technology in the training of specialists in the field of sewing production is considered in the works (Romeo, 2008). In the modern world, information and communication technologies are introduced into almost all spheres of human life, including the professional activity of a light industry technologist.

\section{Methods}

Analysis of the current state of light industry enterprises suggests that technologists must be able to work with various software products that allow automating technological processes. Such software products include computer-aided design (CAD) systems, production technology automation (CAM) systems, and other software packages (including hybrid ones). This software allows you to create and modify technical documentation, process the results of technological experiments, automate the design and manufacture of light industry products and much more.

State-of-the-art CAD / CAM (Computer Aided Design \& Computer Aided Manufacture) software enables faster and more efficient work systems by improving accuracy, productivity and organized information flow (Dāboliņa \& Viḷumsone, 2012).

In this regard, universities are faced with the task of preparing highly qualified light industry technologists, to form their competence in the field of ICT (ICT competence). Highly qualified ICT-competent technologists will be mobile in the constantly changing labor market, therefore, they will be competitive and in demand.

\section{Result and Discussion}

Computer technology is of great importance for design activities. Computer technologies in costume design are used primarily in computer-aided design systems for clothing structure. Modern CAD systems allow you to design a basic structure based on dimensional characteristics; constructive modeling of the drawing; design of patterns of product details; gradation of patterns for details of clothing; creation of layouts of patterns of parts; registration of design and technological documentation; calculation of material consumption. Most modern CAD systems make it possible to design a technical and artistic sketch, select a color scheme for a model, etc.

CAD is becoming popular for its simplicity and precision in drafting (Jeyapoovan, 2005). With $\mathrm{CAD}$, designs can be created faster, with more precision in drawings. In addition, special drawing techniques can be used, and computations are quick and excellent (Sarcar et al., 2008).

Using even standard graphics programs Corel Draw, Illustrator and Photoshop, the designer can draw sketches of clothing styles, technical drawing of the model, construction and gradation of clothing patterns, lay out patterns on the canvas for cost-effective cutting. You can also create an archive of certain types and shapes of parts and product styles (qizi Umarova, 2020).

When designing a new model of clothing, several interpretations of its image are created in order to avoid misunderstandings between designers, constructors, technologists: creative sketch; technical drawing. 
A creative sketch of clothing is an image of the collection's models with a detailed drawing of not only the general form of clothing, but also its individual elements, however, unlike the technical drawing of the model, the image of the costume is important in this sketch.

Technical drawing is one of the most important types of illustrations used in the model development process to visually represent a product. It accurately conveys the silhouette, proportions, constructive solution and details and presents clear, neatly traced lines that carry a single meaning. Technical drawings are a form of visual communication between a designer and a manufacturer. A technical drawing is an image of clothing on a plane without the model's figure, with an emphasis on construction, showing dividing lines and the presence of decorative stitches, planks or other details. It must be completely accurate and schematic, and can be done manually or with the help of graphic editors. When developing a technical drawing, different line widths can be used. The assortment is also presented in technical drawings to create the correct design and color scheme for the entire clothing line within the seasonal collection.

Technical description, the design document of the model, includes the specification and technical drawing of the model (front view and rear view). In the technical drawing, you can indicate the dimensions of the product parts required for the production of clothing and control measurements (length, width, distance).

Technical drawings are often posted on trend books for the coming period and on the websites of clothing manufacturers.

Visual merchandisers can use technical drawings to develop an in-store presentation plan. Fashion magazines with patterns, as a rule, use technical drawing with a front view and a back view, so that information about the design, model details, is clear to every buyer. They are often accompanied by the color scheme used in the model. Enlarged small parts and a side view of the product can be shown.

Thus, technical drawing is a kind of graphic presentation of a costume that a costume designer must own and that accompanies the design and production of clothing in mass production, in ateliers, workshops, design studios, stores, fashion magazines, as well as wherever it comes to fashion and clothing (Uden et al., 2007)

\section{Conclusion}

The development of technical progress, the introduction of computer technology and new information technologies in all spheres of life and production determines the demand for specialists who meet the level of development of the information society, including design. Costume designers, like all designers, need to be familiar with computer technology and analytical processing methods of information, which will help the specialist to adapt to active creativity and a changing environment. Computer technology in clothing design is a universal tool at all stages of project activities, from the creation of artistic and technical sketches, from the construction of a model structure to the development of corporate brands and brand advertising. In short, Vocational Education Costume design achieves educational effectiveness by enhancing students 'creative thinking skills, independent decision-making and teamwork skills through the use of modern information and communication technologies in developing students' competencies in designing and modeling clothing.

\section{References}

Abowd, G. D. (1999). Classroom 2000: An experiment with the instrumentation of a living educational environment. IBM systems journal, 38(4), 508-530.

Dabolina, I., \& Vilumsone, A. (2012). The Role of the Latest Clothing CAD/CAM System Applications in the Educational Process. Material Science (1691-3132), (7). 
Jeyapoovan, T. (2005). Engineering drawing \& Graphics Using AutoCAD. Vikas Publishing House.

Karimov, I. A. (1997). Barkamol avlod-O’zbekiston taraqqiyotining poydevori. T. Sharq.

Monks, A. (2009). The actor in costume. Macmillan International Higher Education.

qizi Umarova, Z. A. (2020). Digital Media Educational Environment: Media Resources and Their Role. Journal of Central Asian Social Studies, 1(01), 66-74.

Respublikasining, O. Z. (1997). Ta'lim to 'g 'risida” gi qonuni Barkamol avlod-O 'zbekiston taraqqiyotining poydevori. T.: Sharq nashriyot-matbaa konserni.

Romeo, G. E. O. F. F. (2008). Information and communication technologies in education. Rethinking Education with ICT: New directions for effective practices. Rotterdam, Sense publishers.

Sarcar, M. M. M., Rao, K. M., \& Narayan, K. L. (2008). Computer aided design and manufacturing. PHI Learning Pvt. Ltd.

Uden, L., Wangsa, I. T., \& Damiani, E. (2007). The future of E-learning: E-learning ecosystem. In 2007 Inaugural IEEE-IES Digital EcoSystems and Technologies Conference (pp. 113-117). IEEE. 